\title{
Synthesis and antifungal activity of new salicylic acid derivatives
}

\author{
Alicja Wodnicka ${ }^{1 *}$, Elżbieta Huzar ${ }^{1}$, Maria Krawczyk ${ }^{2}$, Halina Kwiecień ${ }^{1}$ \\ ${ }^{1}$ West Pomeranian University of Technology, Szczecin, Faculty of Chemical Technology and Engineering, Institute \\ of Organic Chemical Technology, al. Piastów 42, 71-065 Szczecin, Poland \\ ${ }^{2}$ Institute of Industrial Organic Chemistry, Annopol 6, 03-236 Warszawa, Poland \\ "Corresponding author: e-mail: alicja.wodnicka@zut.edu.pl
}

\begin{abstract}
A simple one-step procedure for synthesis of 1-methoxy-1-oxoalkan-2-yl salicylates and 1-methoxy-1-oxoalkan-2-yl 2-[(1-methoxy-1-oxoalkan-2-yl)oxy]benzoates by reaction of salicylic acid with several methyl 2-bromoalkanoates was developed. The reactions were carried out in $N, N$-dimethylformamide (DMF) in the presence of anhydrous potassium carbonate. Conditions for regioselective synthesis of target compounds were established. The developed procedure could be easily applied in the industrial production process. The new salicylic acid derivatives were obtained with satisfactory yields and were characterized by MS and ${ }^{1} \mathrm{H}$ NMR spectra. The fungicidal activity of the prepared compounds was tested in vitro against seven species of plant pathogenic fungi. The best results were observed for 1-methoxy-1-oxoalkan-2-yl salicylates which showed moderate or good activity against Botrytis cinerea and Rhizoctonia solani.
\end{abstract}

Keywords: salicylic acid, salicylates, antifungal activity.

\section{INTRODUCTION}

The plant diseases can cause significant losses of crops before and after harvest, even up to $25 \%{ }^{1}$. Moreover, postharvest diseases limit the storage period and marketing life of many crops, especially fruits like apples, strawberries, grapes and peaches. Some of the most common symptoms of plant diseases are mould, rot and rust, caused by fungal infections ${ }^{2}$. The damage of plant tissues generally results from the action of pectinolytic enzymes produced by fungi ${ }^{3,4}$.

The fungi do not only cause decay of crops but also produce the carcinogenic mycotoxins, e.g. patulin. These toxins may rise to unacceptable levels in fruits or vegetables destined for further processing, creating a threat to consumers ${ }^{4,5}$.

Current control of postharvest crop diseases consists mainly of the use of synthetic chemical fungicides, for example belonging to imidazole, benzimidazole, phenylpyrrole and dicarboximide groups ${ }^{6,7}$. The excessive use of synthetic fungicides has caused an increase of public concern over their possible impact on human health, due to the presence of fungicide residues in food and in the environment $t^{8-11}$. On the other hand, it is also the reason of development of pathogens resistance to fungicides ${ }^{12}$. Therefore, it is important to develop more environmentally friendly compounds as alternative agents for postharvest diseases control.

In the last years, the application of salicylic acid in crop protection has been extensively investigated. Salicylic acid and its derivatives (i.e. aspirin, methyl salicylate, salol, salicylanilide) are known primarily as analgesic, antipyretic, antioxidant, antimicrobial, antiproliferative and cytotoxic agents ${ }^{13-15}$ widely used in medicine. However, many research laboratories are focused currently on the antifungal activity of salicylic acid. It seems to be a good idea because salicylic acid is a natural phenolic hormone produced in plants via the phenylpropanoid pathway as a signalling molecule which plays a critical role in plant defence against a number of fungi and other pathogens ${ }^{\mathbf{1 6}}$. Antifungal activity of salicylic acid was proved against several postharvest pathogens, including
Botrytis cinerea ${ }^{17,}{ }^{18}$, Fusarium oxysporum ${ }^{19}$, Penicillium expansum $^{4,6,20}$ and Rhizopus stolonifer ${ }^{21,22}$. The mentioned fungal strains cause problems during the storage of apples, peaches, sweet cherries, strawberries, tomatoes, potatoes and many others crops.

Only a few authors have reported the antifungal activity of salicylic acid derivatives. Amborabé et al. ${ }^{23}$ have described various activities of several compounds against Eutypa lata, and the best results were obtained for synthetic 4-chlorosalicylic acid. Unfortunately, this substance seems to be unfriendly for the environment because of chlorine content. Antifungal activity is also characteristic for anacardic acid, which is a natural mixture of 6-alkylsalicylic acids (the alkyl groups are saturated or unsaturated chains containing 15 or 17 carbon atoms). Prithiviraj et al. ${ }^{24}$ have proved that these substances can be utilized in controlling certain plant diseases caused by Colletotrichum capsici. These results are encouraging for further development of salicylic acid derivatives as potential antifungal agents.

Bearing the above in mind, the aim of this work was the synthesis of new compounds by the reaction of salicylic acid with methyl 2-bromoalkanoates in alkaline conditions and to establish favourable parameters for the regioselective synthesis of corresponding compounds. The obtained new derivatives of salicylic acid were screened for antifungal activity using in vitro tests.

\section{EXPERIMENTAL}

\section{Chemicals and apparatus}

Starting salicylic acid ( $\geq 99 \%$ purity) was purchased from Alfa Aesar. Methyl 2-bromoalkanoates i.e. methyl 2-bromobutanoate, 2-bromopentanoate and 2-bromohexanoate were obtained according to the method described in the literature ${ }^{25}$, although they are commercially available. Other reagents and solvents were purchased in commercially available grade purity $(>98 \%) . N, N$ -Dimethylformamide (DMF) was dried over 4A molecular sieves. All other reagents and solvents were used without purification. 
The GC-MS analysis of the obtained products was carried out using an Agilent 6890 gas chromatograph equipped with an Agilent 5973 Network Mass Selective Detector (MSD). The separation was effected using a HP-5MSI capillary column with bonded (5\% phenyl) methylpolysiloxane stationary phase $(30 \mathrm{~m} \times 0.25 \mathrm{~mm}$ I.D., $0.25 \mu \mathrm{m}$ film thickness). The GC oven temperature was programmed: initial temperature $60^{\circ} \mathrm{C}$ (hold for $3 \mathrm{~min}$ ); ramp rate $10^{\circ} \mathrm{C} / \mathrm{min}$; final temperature $300^{\circ} \mathrm{C}$ (hold for $10 \mathrm{~min}$ ). Helium was used as a carrier gas at a constant flow rate of $1.2 \mathrm{ml} / \mathrm{min}$. The mass selective detector was working in electron impact mode $(70 \mathrm{eV})$. The mass spectra were scanned in the range from 50 to $500 \mathrm{~m} / \mathrm{z}$.

${ }^{1} \mathrm{H}$ NMR spectra were recorded in $\mathrm{CDCl}_{3}$ with TMS as an internal standard on a TM Bruker DPX 400 spectrometer $(400 \mathrm{MHz})$.

Melting points were determined using a Boetius apparatus and are uncorrected.

\section{Synthesis of methyl 2-bromoalkanoates (2a-2c)}

According to method described by Reinheckel ${ }^{25}$, methyl 2-bromoalkanoates are synthesized in three-step procedure involving chlorination, bromination and esterification of an adequate alkanoic acid with thionyl chloride, bromine and methanol, correspondingly. This synthesis requires a few steps, but it is carried out according to the one-pot procedure. The crude 2-bromoesters were purified by distillation process under reduced pressure and were identified using GC-MS method. All methyl 2-bromoalkanoates (2a-2c) were obtained as colourless oils. The yields and boiling points of 2-bromoesters were correspondingly: $93 \%$ and $49-51^{\circ} \mathrm{C} / 11 \mathrm{mmHg}$ (Lit. ${ }^{26}$ $52-54^{\circ} \mathrm{C} / 11 \mathrm{mmHg}$ ) for methyl 2-bromobutanoate (2a); $95 \%$ and $59-63^{\circ} \mathrm{C} / 10 \mathrm{mmHg}\left(\right.$ Lit. $^{26} 71^{\circ} \mathrm{C} / 13 \mathrm{mmHg}$ ) for methyl 2-bromopentanoate (2b); $93 \%$ and $88-90^{\circ} \mathrm{C} / 14$ mmHg (Lit. ${ }^{26}$ 92-94 $\mathrm{C} / 15 \mathrm{mmHg}$ ) for methyl 2-bromohexanoate (2c).

\section{Synthesis of target compounds $3 a-3 c$ and $4 a-4 c$}

The mixture of salicylic acid (1), methyl 2-bromoalkanoate (2a-2c) and anhydrous $\mathrm{K}_{2} \mathrm{CO}_{3}$ in DMF was heated with stirring at $92-94^{\circ} \mathrm{C}$. The amount of salicylic acid (1) was $18 \mathrm{mmol}$ in each entry and the applied volume of the solvent (DMF) was $50 \mathrm{~mL}$. The molar ratio of reagents and the reaction time are presented in Table 1 . After the completion of the reaction the mixture was poured into ice-water. The products were extracted with methylene chloride and separated preparatively. For this purpose the organic layer was extracted with $5 \%$ sodium hydroxide solution. During this operation 1-methoxy-1-oxoalkan-2-yl salicylates $(\mathbf{3 a - 3 c})$ formed sodium phenolates soluble in water, whereas 1-methoxy-1-oxoalkan-2-yl 2-[(1-methoxy-1-oxoalkan-2-yl)oxy]benzoates $(\mathbf{4 a - 4 c})$ were still remaining in organic solvent. Separated water layer was neutralized with $5 \%$ hydrochloric acid and then compounds 3a-3c were re-extracted with methylene chloride. The obtained methylene chloride extracts containing separated compounds were washed with water and dried over anhydrous sodium sulfate for $30 \mathrm{~min}$. Next, the solvent was evaporated under reduced pressure and pure compounds were dried at room temperature.

The above general procedure was applied for the synthesis of 1-methoxy-1-oxoalkan-2-yl salicylates (3b and 3c) and 1-methoxy-1-oxoalkan-2-yl 2-[(1-methoxy-1-oxoalkan-2-yl)oxy]benzoates (4a-4c). However, in the synthesis of 1-methoxy-1-oxobutan-2-yl salicylate (3a), after pouring the reaction mixture into ice-water the precipitate was formed. It was filtered off, washed with water and dried in air.

\section{Antifungal activity}

The biological experiments were performed by the Laboratory of Department of Applications and Formulation of Pesticides, Institute of Industrial Organic Chemistry in Warsaw. The fungicidal activity of the prepared compounds was tested in vitro against seven species of plant pathogenic fungi: Alternaria alternata, Botrytis cinerea, Fusarium culmorum, Fusarium graminarum, Phythophtora infestans, Phythophtora cactorum, and Rhizoctonia solani. All strains of the fungi were from the collection of the Institute.

Antifungal activity of the obtained compounds $\mathbf{3 a - 3} \mathbf{c}$ and $\mathbf{4 a - 4} \mathbf{c}$ was assayed using a mycelia growth inhibition method. The test was performed by applying the agar discs containing PDA medium mixed with the tested substances. For this purpose, the target compounds were dissolved in acetone to obtain the concentration of $200 \mathrm{mg} / \mathrm{L}$ and the solutions were mixed with molten agar after autoclaving $(15 \% \mathrm{v} / \mathrm{v}$ relative to the PDA medium). The homogeneous mixture was poured in the sterilized Petri dishes. Control plates contained PDA with acetone only. The fungi mycelia were taken from the edge of a good fungal culture and placed in the centre of each Petri dish. After a few days, depending on the growth of mycelium in the control combination, the linear growth of each strain was measured. The fungicidal activity of the tested compounds was expressed as a percentage inhibition of mycelium compared to the control combination. Each measurement consisted of

Table 1. The reaction of salicylic acid (1) with methyl 2-bromoalkanoates (2a-2c) in DMF

\begin{tabular}{|c|c|c|c|c|c|c|}
\hline \multirow{2}{*}{ Entry } & \multirow{2}{*}{$\begin{array}{c}\text { Methyl } \\
\text { 2-bromoalkanoate }\end{array}$} & \multicolumn{2}{|c|}{ Molar ratio } & \multirow{2}{*}{ Reaction time $[\mathrm{h}]$} & \multicolumn{2}{|c|}{ Yield [\%] } \\
\hline & & $1: 2 a-2 c$ & $1: \mathrm{K}_{2} \mathrm{CO}_{3}$ & & $3 a-3 c$ & $4 a-4 c$ \\
\hline 1 & $2 a$ & $1: 1.0$ & $1: 0.55$ & 1 & 89.3 & - \\
\hline 2 & $2 a$ & $1: 2.0$ & $1: 2.50$ & 4 & 2.2 & 91.3 \\
\hline 3 & $2 a$ & $1: 2.5$ & $1: 2.50$ & 2 & 18.6 & 75.7 \\
\hline 4 & $2 b$ & $1: 1.0$ & $1: 0.55$ & 1 & 82.1 & - \\
\hline 5 & $2 b$ & $1: 1.0$ & $1: 1.10$ & 1 & 67.4 & 1.4 \\
\hline 6 & $2 b$ & $1: 2.0$ & $1: 2.00$ & 4 & 11.2 & 77.3 \\
\hline 8 & $2 c$ & $1: 1.0$ & 1:0.55 & 1 & 87.6 & - \\
\hline 9 & $2 c$ & $1: 2.0$ & $1: 2.50$ & 4 & 1.4 & 94.0 \\
\hline 10 & $2 c$ & $1: 2.5$ & $1: 2.50$ & 2 & 23.8 & 71.2 \\
\hline 11 & $2 c$ & $1: 2.5$ & $1: 2.50$ & 4 & 1.2 & 93.7 \\
\hline
\end{tabular}


three replicates and percentage mycelia inhibition was calculated according to the formula:

Growthinhibiton $=\frac{D_{c}-D_{t}}{D_{c}} \times 100(\%)$

where:

$D_{c}$ - is the mean diameter of colony in the control $(\mathrm{mm}), D_{t}-$ is the mean diameter of colony in the Petri dishes with the tested compound (mm).

\section{RESULTS AND DISCUSSION}

\section{Chemistry}

In order to obtain several new salicylic acid derivatives (3a-3c and 4a-4c), salicylic acid (1) was treated with methyl 2-bromoalkanates $(\mathbf{2} \mathbf{a}-\mathbf{2 c})$. The reactions (Scheme 1) were carried out in an aprotic polar solvent $-N, N$-dimethylformamide (DMF) under alkaline conditions, and for this purpose anhydrous potassium carbonate was used. Depending on the reaction conditions, different products $(\mathbf{3 a}-\mathbf{3 c}$ or/and $\mathbf{4 a - 4 c})$ were formed due to the presence of two possible centres of reactivity in the starting salicylic acid (carboxyl and hydroxyl groups). The yields of target compounds $\mathbf{3 a - 3} \mathbf{c}$ and $\mathbf{4 a - 4 c}$ are presented in Table 1.

Conducting the reaction for one hour at the equimolar ratios of the reactants $(\mathbf{1}: \mathbf{2 a} \mathbf{a}-\mathbf{2} \mathbf{c})$ favours the formation of 1-methoxy-1-oxoalkan-2-yl salicylates (entries 1, 4, 5 and 8). Influence of potassium carbonate on both selectivity and efficiency of process was also observed. The molar ratio of the salicylic acid to potassium carbonate of 1:1.1 in the entry 5 led to formation of 1-methoxy-1-oxopentan-2-yl salicylate (3b) in $67.4 \%$ yield. Unfortunately, under these conditions 1-methoxy-1-oxopentan-2-yl 2-[(1-methoxy-1-oxopentan-2-yl)oxy]benzoate (4b) was also formed as a by-product in $1.4 \%$ yield. Reduction of the amount of potassium carbonate in the entries 1,4 and 8 resulted in an increase selectivity of the process. At the molar ratio of reactants of 1:0.55 $\left(1: \mathrm{K}_{2} \mathrm{CO}_{3}\right)$ the pure products $\mathbf{3 a - 3 \mathbf { c }}$ were obtained in $82.1-89.3 \%$ yields.

According to the literature ${ }^{27-30}$, esters of phenolic acids are usually obtained in three-step synthesis. The first step is the protection of hydroxyl group, and as the blocking agents benzyl halides or acetic anhydride are often applied. The ester is formed in the next step and the final stage is removal of the protecting group. The hydrogenolysis is performed, when benzyl is the leaving group. For removal of acetyl group, the hydrolysis is recommended. Application of protecting groups is commonly used at the initial development of synthesis or in small-scale laboratory work, but it is inconvenient in industrial production - additional steps and materials raise the costs of the process. In contrast to the methods described in the literature, the method proposed in this work is one-stage and occurs in good yields. It seems to be easy to transfer to a large scale production.

In case of 1-methoxy-1-oxoalkan-2-yl 2-[(1-methoxy-1-oxoalkan-2-yl)oxy]benzoates (4a-4c) synthesis, the molar ratios of salicylic acid (1) to 2-bromoesters (2a-2c) were $1: 2.0$ or 1:2.5. Comparing the results from entries 9 and 11 it can be stated that the applied ratio of reactants had no influence on the yield of the target compound $\mathbf{4 c}$, so the use of stoichiometric amounts of salicylic acid (1) and 2-bromoesters (2a-2c) should be preferred from an economic point of view. For the synthesis of compounds $4 a-4 c$ the substantial factors were the amount of applied anhydrous potassium carbonate and the time of reaction. The molar ratio of salicylic acid (1) to potassium carbonate of 1:2.0 during the synthesis of compound $\mathbf{4 b}$ (entry 6) resulted in formation of the target product in $77.3 \%$ yield. The rise of process efficiency to $91.3-94.0 \%$ was observed when the bigger amount of potassium carbonate was applied, as in the entries 2, 7 and 9. The results obtained from trials 10 and 11 indicate that it is preferable to conduct the process for four hours.

All obtained 1-methoxy-1-oxoalkan-2-yl salicylates (3a3c) and 1-methoxy-1-oxoalkan-2-yl 2-[(1-methoxy-1-oxoalkan-2-yl)oxy]benzoates $(\mathbf{4 a - 4 c )}$ are novel compounds. 1-methoxy-1-oxobutan-2-yl salicylate (3a) was obtained as a colourless solid with melting point of $27^{\circ} \mathrm{C}$. The others new substances were obtained in a form of colourless oils. Their structures were confirmed by $\mathrm{MS}$ and ${ }^{1} \mathrm{H}$ NMR spectra. Data obtained from analyses performed

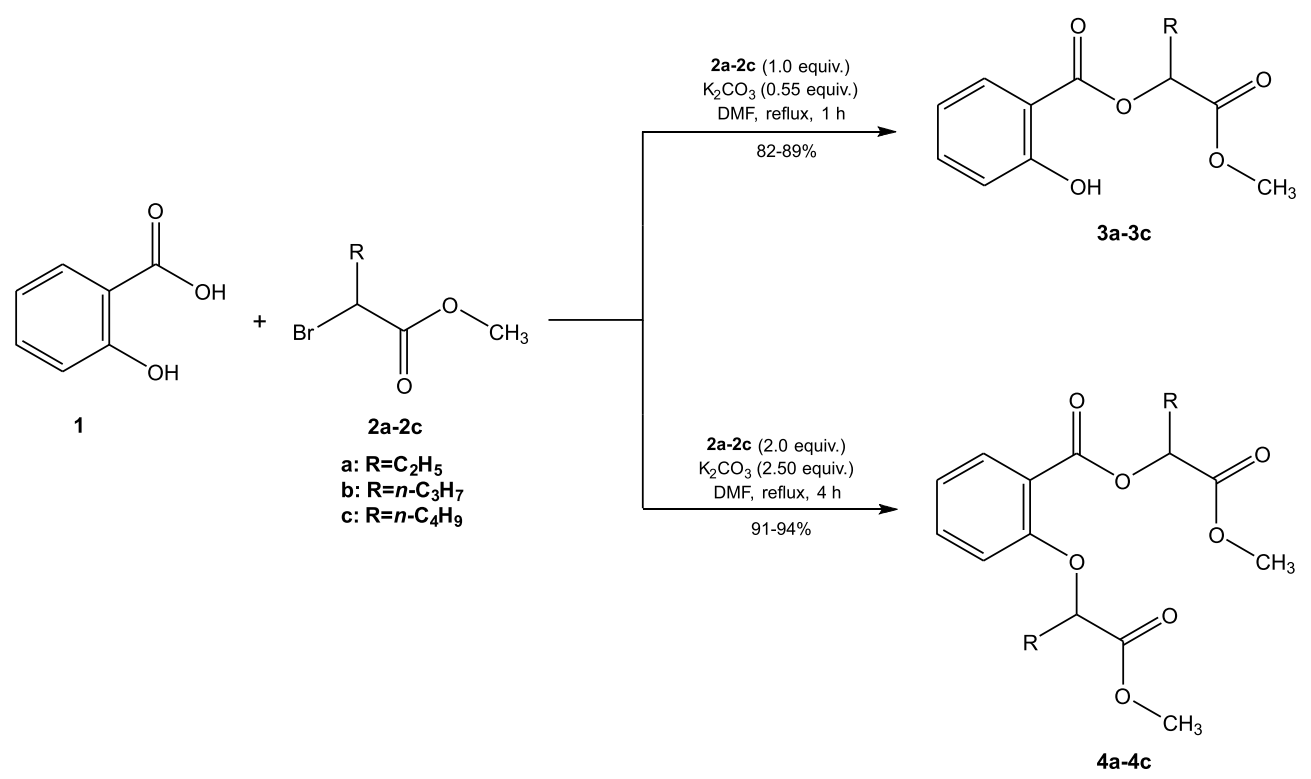

Scheme 1. Synthesis of 1-methoxy-1-oxoalkan-2-yl salicylates (3a-3c) and 1-methoxy-1-oxoalkan-2-yl 2-[(1-methoxy-1-oxoalkan-2-yl) oxy]benzoates $(4 a-4 c)$ 
by gas chromatography-mass spectrometry (GC-MS) are presented in Table 2, whereas ${ }^{1} \mathrm{H}$ NMR spectral data of compounds $\mathbf{3 a - 3 c}$ and $\mathbf{4 a - 4 c}$ are collected in Table 3 .

Table 2. GC-MS data of compounds $3 a-3 c$ and $4 a-4 c$

\begin{tabular}{|c|c|c|}
\hline Compound & $\begin{array}{c}\text { Retention } \\
\text { time [min] }\end{array}$ & Mass/charge [relative intensity] \\
\hline $3 a$ & 15.91 & $\begin{array}{l}238\left(\mathrm{M}^{+}, 78\right), 207(6), 206(12), 178 \\
(10), 138(15), 122(10), 121(93), \\
120(100), 93(19), 92(35), 69(6) \\
65(25), 64(6), 63(6), 59(15)\end{array}$ \\
\hline $3 b$ & 16.86 & $\begin{array}{l}252\left(\mathrm{M}^{+}, 84\right), 221(6), 220(10), 192 \\
(12), 138(28), 122(11), 121(94), \\
120(100), 115(14), 93(21), 92(32), \\
83(11), 73(10), 65(26), 64(6), 63 \\
(5), 59(9), 55(15)\end{array}$ \\
\hline $3 c$ & 17.80 & $\begin{array}{l}266\left(\mathrm{M}^{+}, 84\right), 235(5), 234(7), 206 \\
(11), 138(37), 129(16), 122(10), \\
121(94), 120(100), 97(14), 93(17), \\
92(24), 87(6), 69(17), 65(21), 59 \\
(6), 55(8)\end{array}$ \\
\hline $4 a$ & 20.75 & $\begin{array}{l}338\left(\mathrm{M}^{+}, 9\right), 279(9), 221(14), 220 \\
(11), 193(29), 192(47), 179(7), 178 \\
(11), 177(75), 162(6), 161(59), 122 \\
(8), 121(100), 120(71), 117(6), 115 \\
(5), 101(7), 94(5), 93(6), 92(14), \\
73(11), 69(6), 65(6), 59(20)\end{array}$ \\
\hline $4 b$ & 21.90 & $\begin{array}{l}366\left(\mathrm{M}^{+}, 8\right), 307(7), 235(8), 207 \\
(21), 193(16), 192(100), 191(69), \\
175(25), 147(6), 138(6), 133(8), \\
122(7), 121(90), 120(55), 115(14), \\
93(5), 92(10), 87(8), 83(9), 73(9), \\
59(10), 55(14)\end{array}$ \\
\hline $4 c$ & 23.23 & $\begin{array}{l}394\left(\mathrm{M}^{+}, 17\right), 335(12), 249(12), 222 \\
(5), 221(39), 216(10), 207(12), 206 \\
(21), 205(100), 193(14), 192(99), \\
189(27), 161(14), 147(12), 138 \\
(12), 133(6), 129(21), 122(10), 121 \\
(99), 120(72), 101(9), 97(16), 93 \\
(6), 92(14), 87(7), 69(26), 65(5), \\
59(9), 55(11)\end{array}$ \\
\hline
\end{tabular}

molecular ion

\section{Fungicidal activity}

The fungicidal activity of the synthesized compounds was calculated as percentage of mycelial growth inhibition of pathogenic fungi (in vitro assays) with respect to the control. The results of antifungal tests were expressed in the scale from 0 (no effect) to 3 (good activity) ${ }^{\mathbf{3 1}}$ and collected in Table 4. The fungicidal activity of the salicylic acid derivatives was proved. Compounds $\mathbf{4 a - 4 c}$ showed weak activity against strains $A$. alternata, $B$. cinerea, $P$. intfestans and $R$. solani. Unfortunately, these compounds did not have any influence on the others fungi growth. The spectrum of antifungal activity of 1-methoxy-1-oxoalkan-2-yl salicylates (3a-3c) was broader and higher than observed for compounds $\mathbf{4 a - 4 c}$. The best results were achieved for compound 3a, which showed good activity against B. cinerea (growth inhibition of $97.0 \%$ ). For this
Table 3. ${ }^{1} \mathrm{H}$ NMR spectral data of compounds $3 \mathrm{a}-3 \mathrm{c}$ and $4 \mathrm{a}-4 \mathrm{c}$

\begin{tabular}{|c|c|}
\hline Compound & ${ }^{1} \mathrm{H}$ NMR $\delta$ [ppm] \\
\hline $3 a$ & $\begin{array}{l}10.49(\mathrm{~s}, 1 \mathrm{H}, \mathrm{OH}), 7.94(\mathrm{dd}, J=8.0,1.7 \mathrm{~Hz}, 1 \mathrm{H}, \\
\mathrm{Ar}), 7.48(\mathrm{ddd}, J=8.6,7.3,1.7 \mathrm{~Hz}, 1 \mathrm{H}, \mathrm{Ar}), 6.99 \\
(\mathrm{dd}, J=8.4,0.8 \mathrm{~Hz}, 1 \mathrm{H}, \mathrm{Ar}), 6.93-6.89(\mathrm{~m}, 1 \mathrm{H}, \\
\mathrm{Ar}), 5.21(\mathrm{dd}, J=6.7,5.5 \mathrm{~Hz}, 1 \mathrm{H}, \mathrm{CH}), 3.78(\mathrm{~s}, 3 \mathrm{H}, \\
\left.\mathrm{OCH}_{3}\right), 2.08-2.01\left(\mathrm{~m}, 2 \mathrm{H}, \mathrm{CH}_{2}\right), 1.09(\mathrm{t}, J=7.4 \\
\left.\mathrm{Hz}, 3 \mathrm{H}, \mathrm{CH}_{3}\right)\end{array}$ \\
\hline $3 b$ & $\begin{array}{l}10.49(\mathrm{~s}, 1 \mathrm{H}, \mathrm{OH}), 7.93(\mathrm{dd}, J=8.1,1.6 \mathrm{~Hz}, 1 \mathrm{H}, \\
\mathrm{Ar}), 7.48(\mathrm{ddd}, J=8.7,7.3,1.7 \mathrm{~Hz}, 1 \mathrm{H}, \mathrm{Ar}), 6.99 \\
(\mathrm{dd}, J=8.4,0.8 \mathrm{~Hz}, 1 \mathrm{H}, \mathrm{Ar}), 6.91(\mathrm{ddd}, J=8.2, \\
7.2,1.1 \mathrm{~Hz}, 1 \mathrm{H}, \mathrm{Ar}), 5.26(\mathrm{dd}, J=7.8,5.0 \mathrm{~Hz}, 1 \mathrm{H}, \\
\mathrm{CH}), 3.78\left(\mathrm{~s}, 3 \mathrm{H}, \mathrm{OCH}_{3}\right), 2.04-1.93\left(\mathrm{~m}, 2 \mathrm{H}, \mathrm{CH}_{2}\right), \\
1.59-1.48\left(\mathrm{~m}, 2 \mathrm{H}, \mathrm{CH}_{2}\right), 0.99(\mathrm{t}, J=7.4 \mathrm{~Hz}, 3 \mathrm{H}, \\
\left.\mathrm{CH}_{3}\right)\end{array}$ \\
\hline $3 c$ & $\begin{array}{l}10.49(\mathrm{~s}, 1 \mathrm{H}, \mathrm{OH}), 7.93(\mathrm{dd}, J=8.1,1.6 \mathrm{~Hz}, 1 \mathrm{H}, \\
\mathrm{Ar}), 7.48(\mathrm{ddd}, \mathrm{J}=8.7,7.2,1.7 \mathrm{~Hz}, 1 \mathrm{H}, \mathrm{Ar}), 6.99 \\
(\mathrm{dd}, J=8.5,0.8 \mathrm{~Hz}, 1 \mathrm{H}, \mathrm{Ar}), 6.91(\mathrm{ddd}, J=8.2 \\
7.2,1.1 \mathrm{~Hz}, 1 \mathrm{H}, \mathrm{Ar}), 5.25(\mathrm{dd}, J=6.5,6.2 \mathrm{~Hz}, 1 \mathrm{H}, \\
\mathrm{CH}), 3.78\left(\mathrm{~s}, 3 \mathrm{H}, \mathrm{OCH}_{3}\right), 2.03-1.97\left(\mathrm{~m}, 2 \mathrm{H}, \mathrm{CH}_{2}\right), \\
1.52-1.37\left(\mathrm{~m}, 4 \mathrm{H}, 2 \mathrm{CH}_{2}\right), 0.94(\mathrm{t}, J=7.2 \mathrm{~Hz}, 3 \mathrm{H}, \\
\left.\mathrm{CH}_{3}\right)\end{array}$ \\
\hline $4 a$ & $\begin{array}{l}\text { 7.93-7.88(m, 1H, Ar), 7.44-7.40 (m, 1H, Ar), 7.02 } \\
(\mathrm{t}, \mathrm{J}=7.5 \mathrm{~Hz}, 1 \mathrm{H}, \mathrm{Ar}), 6.79(\mathrm{~d}, \mathrm{~J}=8.4 \mathrm{~Hz}, 1 \mathrm{H}, \mathrm{Ar}), \\
5.27-5.23(\mathrm{~m}, 1 \mathrm{H}, \mathrm{CH}), 4,71-4.67(\mathrm{~m}, 1 \mathrm{H}, \mathrm{CH}), \\
3.76\left(\mathrm{~s}, 3 \mathrm{H}, \mathrm{OCH}_{3}\right), 3.73\left(\mathrm{~d}, \mathrm{~J}=2.3 \mathrm{~Hz}, 3 \mathrm{H}, \mathrm{OCH}_{3}\right), \\
2.05-1.88\left(\mathrm{~m}, 4 \mathrm{H}, 2 \mathrm{CH}_{2}\right), 1.01-0.92(\mathrm{~m}, 6 \mathrm{H}, 2 \\
\left.\mathrm{CH}_{3}\right)\end{array}$ \\
\hline $4 b$ & $\begin{array}{l}\text { 7.94-7.88(m, 1H, Ar), 7.44-7.40 (m, 1H, Ar), 7.02 } \\
(\mathrm{t}, J=7.5 \mathrm{~Hz}, 1 \mathrm{H}, \mathrm{Ar}), 6.79(\mathrm{~d}, J=8.4 \mathrm{~Hz}, 1 \mathrm{H}, \mathrm{Ar}), \\
5.28-5.24(\mathrm{~m}, 1 \mathrm{H}, \mathrm{CH}), 4,71-4.67(\mathrm{~m}, 1 \mathrm{H}, \mathrm{CH}), \\
3.77\left(\mathrm{~s}, 3 \mathrm{H}, \mathrm{OCH}_{3}\right), 3.73(\mathrm{~d}, J=2.4 \mathrm{~Hz}, 3 \mathrm{H}, \\
\left.\mathrm{OCH}_{3}\right), 2.05-1.90\left(\mathrm{~m}, 4 \mathrm{H}, 2 \mathrm{CH}_{2}\right), 1.57-1.53(\mathrm{~m}, \\
\left.4 \mathrm{H}, 2 \mathrm{CH}_{2}\right), 1.00-0.94\left(\mathrm{~m}, 6 \mathrm{H}, 2 \mathrm{CH}_{3}\right)\end{array}$ \\
\hline $4 c$ & $\begin{array}{l}\text { 7.92-7.87(m, 1H, Ar), 7.45-7.40 (m, 1H, Ar), } 7.02 \\
(\mathrm{t}, J=7.6 \mathrm{~Hz}, 1 \mathrm{H}, \mathrm{Ar}), 6.80(\mathrm{~d}, \mathrm{~J}=8.4 \mathrm{~Hz}, 1 \mathrm{H}, \mathrm{Ar}), \\
5.26-5.22(\mathrm{~m}, 1 \mathrm{H}, \mathrm{CH}), 4,70-4.66(\mathrm{~m}, 1 \mathrm{H}, \mathrm{CH}), \\
3.76\left(\mathrm{~s}, 3 \mathrm{H}, \mathrm{OCH}_{3}\right), 3.73(\mathrm{~d}, \mathrm{~J}=2.0 \mathrm{~Hz}, 3 \mathrm{H}, \\
\left.\mathrm{OCH}_{3}\right), 2.05-1.87\left(\mathrm{~m}, 4 \mathrm{H}, 2 \mathrm{CH}_{2}\right), 1.57-1.44(\mathrm{~m}, \\
\left.4 \mathrm{H}, 2 \mathrm{CH}_{2}\right), 1.43-1.32\left(\mathrm{~m}, 4 \mathrm{H}, 2 \mathrm{CH}_{2}\right), 0.96-0.88 \\
\left(\mathrm{~m}, 6 \mathrm{H}, 2 \mathrm{CH}_{3}\right)\end{array}$ \\
\hline
\end{tabular}

strain of fungi quite good results were also observed in case of derivatives $\mathbf{3 b}$ and $\mathbf{3 c}$. The fungistatic effect of these substances was about $87 \%$. It can be stated that 1-methoxy-1-oxoalkan-2-yl salicylates (3a-3c) could be used to control grey mould which is caused by $B$. cinerea. These compounds also showed moderate activity against $R$. solani (the growth inhibition was in the range from 63 to $88 \%$ ). Moreover, 1-methoxy-1-oxohexan-2-yl salicylate (3c) and 1-methoxy-1-oxopentan-2-yl salicylate (3b) caused substantial inhibition of $P$. cactorum and P. intfestans, respectively. As well as substances $\mathbf{4 a - 4 c}$, 1-methoxy-1-oxoalkan-2-yl salicylates (3a-3c) slightly inhibited the growth of $A$. alternata $(33-46 \%)$ and were ineffective against Fusarium strains.

Summarizing, our data demonstrate that salicylic acid derivatives $\mathbf{3 a}-\mathbf{3 c}$ and $\mathbf{4 a - 4}$ act on the development of

Table 4. Fungicidal activity of the synthesized new salicylic acid derivatives (in vitro test)

\begin{tabular}{|c|c|c|c|c|c|c|c|}
\hline \multirow[b]{2}{*}{ Compound } & \multicolumn{7}{|c|}{ Effect of the synthesized substances on the mycelial growth ${ }^{a}$} \\
\hline & $\begin{array}{c}\text { Alternaria } \\
\text { alternata }\end{array}$ & $\begin{array}{l}\text { Botrytis } \\
\text { cinerea }\end{array}$ & $\begin{array}{l}\text { Fusarium } \\
\text { culmorum }\end{array}$ & $\begin{array}{c}\text { Fusarium } \\
\text { graminarum }\end{array}$ & $\begin{array}{c}\text { Phytophtora } \\
\text { cactorum }\end{array}$ & $\begin{array}{c}\text { Phytophtora } \\
\text { infestans }\end{array}$ & $\begin{array}{c}\text { Rhizoctonia } \\
\text { solani }\end{array}$ \\
\hline $3 a$ & 1 & 3 & 0 & 0 & 1 & 1 & 2 \\
\hline $3 b$ & 1 & 2 & 0 & 1 & 1 & 2 & 2 \\
\hline $3 c$ & 1 & 2 & 0 & 0 & 2 & 1 & 2 \\
\hline $4 a$ & 1 & 1 & 0 & 0 & 0 & 1 & 1 \\
\hline $4 b$ & 1 & 1 & 0 & 0 & 0 & 1 & 1 \\
\hline $4 \mathrm{c}$ & 1 & 1 & 0 & 0 & 0 & 1 & 1 \\
\hline
\end{tabular}

${ }^{a}$ Scale: 0 - no effect (0-20\% growth inhibition), 1 - weak activity (20.1-50\% growth inhibition), 2 - moderate activity (50.1-90\% growth inhibition), 3 - good activity (90.1-100\% growth inhibition) 
5 from 7 tested fungal pathogens. This action seems to be specific to the molecular structure. Substitution of the hydroxyl group in the salicylic acid (compounds $\mathbf{4 a - 4 c )}$ reduced the antifungal activity in comparison to the compounds with free hydroxyl group. A similar observation had also been made by Amborabé et al., who tested antifungal effects of other salicylic acid derivatives towards E. lata fungi strain ${ }^{23}$.

\section{CONCLUSIONS}

We have reported an efficient method for the synthesis of new salicylic acid derivatives i.e. 1-methoxy-1-oxoalkan-2-yl salicylates (3a-3c) and 1-methoxy-1-oxoalkan-2-yl 2-[(1-methoxy-1-oxoalkan-2-yl)oxy]benzoates (4a-4c). Conditions for selective synthesis of target compounds in the one-step procedure were established. The short time of reaction, especially during synthesis of 1-methoxy-1-oxoalkan-2-yl salicylates (3a-3c) favours energy saving and application the only necessary quantity of reagents allows to minimize the amount of generated by-products and waste. It seems to be in line with the current trends in green chemistry and green chemical technology.

Antifungal activity of the obtained compounds was assayed using a mycelia growth inhibition method. The results of the preliminary tests showed some activity against five different strains of phytopathogenic fungi. The best results were achieved for compounds $\mathbf{3 a - 3 c}$ which showed moderate or good activity against $B$. cinerea and $R$. solani. Syntheses of novel derivatives of the other phenolic acids and their biological properties will be the subject of our further studies in this area. It is intentional to focus on derivatives with free hydroxyl group.

\section{LITERATURE CITED}

1. Donmez, M.F., Esitken, A., Yildiz, H. \& Ercisli, S. (2011). Biocontrol of Botrytis cinerea on strawberry fruit by plant growth promoting bacteria. J. Anim. Plant Sci. 21(4), 758-763.

2. Barker, A.V. (2010). Science and technology of organic farming. Boca Raton, USA: CRC Press.

3. Vilanova, L., Viñas, I., Torres, R., Usall, J., Buron-Moles, G. \& Teixidó, N. (2014). Acidification of apple and orange hosts by Penicillium digitatum and Penicillium expansum. Int. J. Food Microbiol. 178, 39-49. DOI: 10.1016/j.ijfoodmicro.2014.02.022.

4. da Rocha Neto, A.C., Luiz, C., Maraschin, M. \& Di Piero, R.M. (2016). Efficacy of salicylic acid to reduce Penicillium expansum inoculum and preserve apple fruits. Int. J. Food Microbiol. 221, 54-60. DOI: 10.1016/j.ijfoodmicro.2016.01.007.

5. da Rocha, M.E.B., Freire, F.C.O., Maia, F.E.F., Guedes, M.I.F. \& Rondina, D. (2014). Mycotoxins and their effects on human and animal health. Food Control 36(1), 159-165. DOI: 10.1016/j.foodcont.2013.08.021.

6. da Rocha Neto, A.C., Maraschin, M. \& Di Piero, R.M. (2015). Antifungal activity of salicylic acid against Penicillium expansum and its possible mechanisms of action. Int. J. Food Microbiol. 215, 64-70. DOI: 10.1016/j.ijfoodmicro.2015.08.018.

7. Feliziani, E. \& Romanazzi, G. (2013, October). Preharvest application of synthetic fungicides and alternative treatments to control postharvest decay of fruit. Stewart Postharvest Rev. 9(3), 1-6. Retrieved July 12, 2016, from http://www.stewartpostharvest.com/articles.shtml.

8. Bajwa, U. \& Sandhu, K.S. (2014). Effect of handling and processing on pesticide residues in food - a review. J. Food Sci. Technol. 51(2), 201-220. DOI: 10.1007/s13197-011-0499-5.
9. Grimalt, S. \& Dehouck, P. (2016). Review of analytical methods for the determination of pesticide residues in grapes. J. Chromatogr. A 1433, 1-23. DOI: 10.1016/j.chroma.2015.12.076.

10. Uclés, A., Valverde, G.A., García, M.D.G., del Real, A.M.A. \& Fernández-Alba, A.R. (2015). Benzimidazole and imidazole fungicide analysis in grape and wine samples using a competitive enzyme-linked immunosorbent assay. Anal. Methods 7(21), 9158-9165. DOI: 10.1039/c5ay01048a.

11. Wightwick, A., Walters, R., Allinson, G., Reichman, S. \& Menzies, N. (2010). Environmental risks of fungicides used in horticultural production systems. In O. Carisse (Ed.), Fungicides (pp. 273-304). InTech. Retrieved July 12, 2016, from http:// www.intechopen.com/books/fungicides. DOI: 10.5772/13032.

12. van den Bosch, F., Paveley, N., Shaw, M., Hobbelen, P. \& Oliver, R. (2011). The dose rate debate: does the risk of fungicide resistance increase or decrease with dose? Plant Pathol. 60(4), 597-606. DOI: 10.1111/j.1365-3059.2011.02439.x.

13. Rainsford, K.D. (Ed.) (2004). Aspirine and related drugs. London, UK: CRC Press.

14. Sahoo, J. \& Paidesetty, S.K. (2015). Antimicrobial, analgesic, antioxidant and in silico study of synthesized salicylic acid congeners and their structural interpretation. Egyp. J. Bas. Appl. Sci. 2(4), 268-280. DOI: 10.1016/j.ejbas.2015.07.006.

15. Djurendić, E., Dojčinović Vujašković, S., Sakač, M., Ajduković, J., Gaković, A., Kojić, V., Bogdanović, G., Klisurić, O. \& Penov Gaši, K. (2011). Synthesis and biological evaluation of some new 2-oxazoline and salicylic acid derivatives. ARKIVOC 2011(2), 83-102. DOI: 10.3998/ark.5550190.0012.207.

16. Vidhyasekaran, P. (2007). Fungal pathogenesis in plants and crops: Molecular biology and host defense mechanisms (2nd ed.). Boca Raton, USA: CRC Press.

17. Wang, Y.Y., Li, B.Q., Qin, G.Z., Li, L. \& Tiana, S.P. (2011). Defense response of tomato fruit at different maturity stages to salicylic acid and ethephon. Sci. Hortic. 129(2), 183-188. DOI: 10.1016/j.scienta.2011.03.021.

18. Zhang, H., Ma, L., Wang, L., Jiang, S., Dong, Y. \& Zheng, X. (2008). Biocontrol of gray mold decay in peach fruit by integration of antagonistic yeast with salicylic acid and their effects on postharvest quality parameters. Biol. Control 47(1), 60-65. DOI: 10.1016/j.biocontrol.2008.06.012.

19. Mandal, S., Mallick, N. \& Mitra, A. (2009). Salicylic acid-induced resistance to Fusarium oxysporum f. sp. lycopersici in tomato. Plant Physiol. Bioch. 47(7), 642-649. DOI: 10.1016/j. plaphy.2009.03.001.

20. Yu, T. \& Zheng, X.D. (2006). Salicylic acid enhances biocontrol efficacy of the antagonist Cryptococcus laurentii in apple fruit. J. Plant Growth Regul. 25(2), 166-174. DOI: 10.1007/s00344-005-0077-z.

21. Panahirad, S., Zaare-Nahandi, F., Safaralizadeh, R. \& Alizadeh-Salteh, S. (2012). Postharvest control of Rhizopus stolonifer in peach (Prunus persica L. Batsch) fruits using salicylic acid. J. Food Safety 32(4), 502-507. DOI: 10.1111/jfs.12013.

22. Qin, X., Xiao, H., Xue, C., Yu, Z., Yang, R., Cai, Z. \& $\mathrm{Si}$, L. (2015). Biocontrol of gray mold in grapes with the yeast Hanseniaspora uvarum alone and in combination with salicylic acid or sodium bicarbonate. Postharvest Biol. Tec. 100, 160-167. DOI: 10.1016/j.postharvbio.2014.09.010.

23. Amborabé, B., Fleurat-Lessard, P., Chollet, J. \& Roblin, G. (2002). Antifungal effects of salicylic acid and other benzoic acid derivatives towards Eutypa lata: structure-activity relationship. Plant Physiol. Bioch. 40(12), 1051-1060. DOI: 10.1016/ S0981-9428(02)01470-5.

24. Prithiviraj, B., Singh, U.P., Manickam, M. \& Ray, A.B. (1997). Antifungal activity of anacardic acid, a naturally occurring derivative of salicylic acid. Can. J. Bot. 75(1), 207-211. DOI: $10.1139 / \mathrm{b} 97-021$.

25. Reinheckel, H. (1960). Über halogen- und stickstoffhaltige Derivate aliphatischer Carbonsäuren, I. Die indirekte $\alpha$-Bromierung von Fettsäureestern. Chem. Ber. 93(10), 2222-2229. DOI: 10.1002/cber.19600931007. 
26. Kwiecień, H. (1996). Synthesis and properties of new 2-alkyl-1,4-benzoxazepine derivatives. Part I. Synthesis and cyclization of 2-phenoxyalkanoic acid derivatives. Pol. J. Chem. 70, 733-741.

27. Catel, Y., Aladedunye, F. \& Przybylski, R. (2010). Synthesis, radical scavenging activity, protection during storage, and frying by novel antioxidants. J. Agric. Food Chem. 58(20), 11081-11089. DOI: 10.1021/jf102287h.

28. Haddleton, D.M., Sahota, H.S., Taylor, P.C. \& Yeate, S.G. (1996). Synthesis of polyester dendrimers. J. Chem. Soc. Perkin Trans. 1 1996(7), 649-656. DOI: 10.1039/P19960000649.

29. Torlopov, M.A., Udoratina, E.V. \& Kuchin, A.V. (2013). Synthesis of inulin esters of phenylcarboxylic acids. Russ. J. Org. Chem. 49(5), 702-706. DOI: 10.1134/S1070428013050114.

30. Spivey, A.C. \& Leese, D. (2002). Synthetic methods. Part (III) Protecting groups. Annu. Rep. Prog. Chem., Sect. B 98, 41-60. DOI: 10.1039/b111463h.

31. Zakrzewski, J. \& Krawczyk, M. (2006). Reactions of nitroxides with sulfur-containing compounds, Part IV: Synthesis of novel nitroxide (thio)ureas. Heteroatom Chem. 17(5), 393-401. DOI: $10.1002 /$ hc.20228. 